\title{
Raising Student Consciousness About Machine Translation
}

\section{Tim Newfields}

Toyo University

\section{Ivan Botev \\ Toita Women's College}

\section{Reference Data}

Newfields, T., \& Botev, I. (2021). Raising student consciousness about machine translation. In P. Clements, R. Derrah, \& P. Ferguson (Eds.), Communities of teachers \& learners. JALT. https:// doi.org/10.37546/JALTPCP2020-48

With the rise of virtual assistants and the proliferation of digital translation software, such as Google Translate and Weblio that speed up the translator's work, it is time to question what role, if any, machine translation services should have in foreign language classes. In this paper, the authors describe some activities designed to raise awareness about the use and misuse of machine translation within a task-based learning framework. Inspired by Sharwood-Smith's 1981 notion of "consciousness-raising", we outline three activities highlighting the benefits and problems of machine translation. An analysis of two translation exercises by 86 tertiary students in Japan indicated how many felt uncertain of the quality of their translations. Moreover, semi-structured interviews with six respondents following these activities underscored how students felt ambivalent about their translations. We conclude the paper with a discussion of some resources for EFL students seeking to improve their translation skills.

デジタル翻訳ソフトの普及に伴い、外国語の授業で機械翻訳サービスが、もしあるとしたらどのような役割を担うべきかを 問う時期にきている。本稿では、タスクベース学習の枠組みの中で、機械翻訳の使用と誤用についての認識を高めるためにデ ザインされたいくつかの活動について説明する。本稿では、機械翻訳の利点と欠点を強調する三つのアクテイビティーを概説 する。日本の高等教育機関で学ぶ86人の学生によるふたつの翻訳演習の分析から、多くの学生が自らの翻訳の質に不安を感 じていることがわかった。、さらに、これらのアクティビティーの後に実施した6人の学部生への半構造化面接から、多くの学生 が翻訳の質を判断するのに苦労していることが明らかになった。締めくくりとして、翻訳スキルの向上を目指すEFLの学生向け のリソースについて考察した。 onsciousness-raising $(\mathrm{C}-\mathrm{R})$ is used in many contexts. It is rooted in "discovery learning" concepts (Bruner, 1961) and emphasizes learning processes to showcase how related lexical materials differ. In this paper, we adopt the description by Rutherford and Sharwood-Smith $(1985$, p. 274$)$ description of C-R as a "deliberate attempt to draw the learner's attention to the formal properties of the target language." C-R activities are often associated with grammar instruction (Bolitho \& Tomlinson, 1980; Ellis, 2002; Rutherford, 1987), or exercises to enhance pragmatic awareness (Bardovi-Harlig \& Griffin, 2005; Tomlinson, 1994). In this article, we consider its use in translation. In it, we introduce exercises to help students assess the strengths and weaknesses of online computer translations and to conceptualize translation uses. We also offer practical advice for those dealing with bilingual texts.

Since students often use online translation tools without post-editing, there is a need to address the problems of relying too much on machine translations such as Google Translate, Weblio, or Naver Papago. Since human contextual post-editing is required to transform text into socio-culturally appropriate target language, it is essential to realize how mistranslations can arise when relying solely on machine output.

\section{Literature Review}

Although C-R activities have been around for decades, their use in translation contexts is more recent. Li (2017) described a two-semester C-R course for twentyone undergraduate translators in Macau. After explaining some common translation techniques, students were asked to translate sentences, then paragraphs, while using those techniques. During the course, students also translated a 1,000+ word document based on their understanding of the translation techniques learned so far. By the end of the course, student reflective journals and SNS logs suggested that most students had mastered the translation techniques highlighted in the course. 
Lee (2019) describes the use of machine translation in a Korean university EFL context. Students compared their own translations of a Korean text with a machine translation to produce a final translation in class. The author noted that machine translation "can be a useful aid to language learning, but for it to benefit student learning, teachers must be aware of its limitations and provide adequate guidance to students" (p. 1). He further remarked that machine translations "functioned similar to peer-editing: neither is perfect, but both are helpful to student writing" (p. 12).

A very basic form of C-R is described by Mizuochi, Kiryu, and Kanzaki (2012) in which 22 sixth grade Japanese elementary school students compared the Japanese and English versions of a Japanese folk tale by using the voice function of Google Translate on computer tablets. This appeared to raise awareness of how Japanese and English sounds differ. Because all students were just starting to learn English, all computer translations were taken at face value and students reported less anxiety about mistakes when working with tablets instead of people.

Finally, Tatsumi (2015) explored a C-R activity in which students considered how metalinguistic and paralinguistic features can change translation results. As a result of her intervention, the author asserts that:

[t]here was a change in the student's translation before and after the translation instruction. Before the translation instruction, the students did not translate by considering the context, but produced the translation by applying the dictionary translations, but after the instruction, they thought about the context more. (p. 71)

Tatsumi's research suggests that some sort of paradigm shift regarding translation did occur among many students. One thing unclear from her research was the extent to which students may have relied on computer translations.

\section{Research Rationale and Questions}

With this current research project, the authors address three gaps. First, we document the prevalence of machine translation in two Japanese tertiary contexts. Second, we also show practical ways to problematize the blind overreliance on machine generated texts. Finally, we introduce alternatives to this reliance for novice EFL students. This study can therefore be framed as a classroom material development case study (Tomlinson, 2003) because problems with the initial materials were analyzed and subsequently revised to become better suited in future Japanese EFL contexts.
In this paper, we attempt to answer four research questions:

RQ1. To what extent did the EFL students in this sample rely on digital translation software or online translation sites to complete their schoolwork?

RQ2. How did the undergraduates in this sample conceptualize the translation process?

RQ\#. What sort of errors did the students make when attempting translations?

RQ4. To what extent, if any, did these activities change how the students regarded machine translations?

\section{Method}

\section{Participants}

The activities described were conducted among 86 students from two tertiary institutions in Tokyo. Twenty-one respondents were economics majors at a private university and the remaining 66 studied "international communication and culture" at a women's college. The demographic characteristics of this sample is summarized in Table 1.

Table 1

Initial Data Collection Participants

\begin{tabular}{|c|c|c|c|c|c|}
\hline \multicolumn{2}{|c|}{ Gender } & \multicolumn{2}{|c|}{ Nationality } & \multicolumn{2}{|c|}{ Academic Year } \\
\hline Male & Female & Japanese & Non-Japanese & 1st Year & 2nd Year \\
\hline 14 & 72 & 78 & 8 & 64 & 22 \\
\hline
\end{tabular}

Respondents ranged in age from 18 to 22 and their CEFR levels varied from B1 to A1, with most at an A2 level. Four respondents were Chinese, two were Vietnamese, one was Mongolian, one was Finnish, and another was a British/Japanese dual national. A smaller convenience sample of six student volunteers participated in semi-structured interviews after all materials were administered. We chose a semi-structured format because it balances consistency with flexibility, permitting clarification of issues raised by respondents while ensuring that core questions were raised (Balushi, 2018).

Interview participants were recruited after the final activity through volunteer sampling. Nine students initially came forward, but three became busy with other activities. Thus, six were interviewed and their characteristics are summarized in Table 
2. These six informants all had TOEIC scores well above the Japanese national average TOEIC score of 517 (ETS, 2018) and were among the most active students in our classes. Classes at both institutions are streamed according to TOEIC scores and we attempted the translation activities only with our two highest ranked classes.

Table 2

Participants in Follow-up Interviews

\begin{tabular}{lccccc}
\hline Pseudonym & Gender & Age & Nationality / L1 & Other Languages & TOEIC \\
\hline Airi & F & 19 & Japanese / Japanese & English, some French & 735 \\
Akari & F & 19 & Japanese / Japanese & English & 560 \\
Reia & F & 19 & Japanese / Japanese & English, some French & 600 \\
Daiki & M & 19 & Japanese / Japanese & English, some Chinese & 750 \\
Esther & F & 21 & Japanese-Brit / Japanese & English & 770 \\
Peppi & F & 27 & Finnish / Japanese & English, Japanese & 985 \\
\hline
\end{tabular}

In all, this project consisted of two groups of informants: 86 undergraduate classroom participants and a sub-set of six undergraduate interviewees.

\section{Ethics}

The first classroom activity included an informed consent statement, and none of the participants chose to opt out of the study. During the interviews, we also asked students to come up with pseudonyms as listed in the tables above. Performance in the activities described in this paper did not impact student grading, so there was no conflict of interest in that regard.

\section{Instruments}

To address the first research question, respondents were asked to translate a 133-character Japanese new year's card into English (Appendix A). After that, they were asked to indicate which computer translation services they used. During the semistructured interviews described in Appendix D, nine questions about computer-assisted translations were raised. To answer the second research question, we relied on seven semi-structured interview questions. To address the third question, the materials in Appendices A-C were helpful. For the final research question, we relied on four semistructured interview questions.

The task in Appendix A was chosen for its seasonal appropriateness and brevity. It came from the new year's postcard collection of Japan's postal service. Although new year's postcards typically employ formulaic language that is daunting to translate, their obligatory nature in business contexts provides a rationale for its use. A computer translation of Appendix A's text was contrasted with two human translations by the researchers in Appendix B. Students were then invited to discuss when literal, free-style, and machine translations were appropriate.

The final task in Appendix $\mathrm{C}$ encourages students to consider some translation resources. Several bilingual concordances, online peer translation services, and volunteer translation communities are described.

\section{Procedure}

Except for the semi-structured interviews, activities were conducted in December 2019 and January 2020. Because of the timing, materials with Christmas and New Year motifs were selected.Translation Exercise 1 was distributed near the end of a December class. After an explanation of the informed consent procedure and invitation for students to opt out, participants were asked to translate the postcard into English. Before teachers collected their papers, students were requested to indicate which apps or translation sites (if any) they used to complete the task.

Later, the notion of translation types was introduced and the materials in Appendix B were distributed. Students were also given 10 minutes at the end of class to complete this activity and their documents were then collected. In the next class, the materials in Appendix $\mathrm{C}$ were distributed and some translation resources were outlined by the instructors, after which students discussed those resources. A call for students to volunteer for individual interviews with the two instructors at their convenience was then made.

The main researcher then coded the papers in Appendices A and B. To code the first activity, the typology recommended by Fujita et al. (2017) was adopted due to its ease of use. The categories in that rubric are summarized in Table 3. 
Table 3

A Typology of Translation Error Types

\begin{tabular}{cl}
\hline Type & Description \\
\hline 1 & missing, unfinished, or incomplete translations \\
2 & contains semantic errors resulting incorrect content \\
3 & grammatical, spelling, or punctuation issues \\
4 & results are overly literal or awkward \\
5 & target text is too formal or too casual \\
6 & appropriately translated; no issues need to be addressed \\
\hline
\end{tabular}

Student interviews were held in February and March 2020. Adopting a semi-structured format described by Kvale (2008), the interview questions were based on studies by PACTE Group (2005), Jones (2011), and Cheng (2017). After informed consent was obtained, the interviews were recorded and interviewers took notes. Student responses to the interview questions were then compared.

\section{Results and Discussion}

$R Q$ 1: To what extent did the EFL students in this sample rely on digital translation software or online translation sites to complete their schoolwork?

To complete the first task, 57 of the informants reported that they relied on some type of machine translation. Forty-five of those doing so chose Google Translate, which is a website and cellphone app. Eight opted for Weblio, which also has dual formats while two respondents used Naver Papago, which appears in similar formats. Two respondents reported using LINE Dict, an app useful for single-word translations that does not handle sentences or phrases. Twenty-nine indicated they used no machine translation.

The interviews provided insights into automatic translation use. Four of the six informants interviewed reported using translation apps. Daiki stated he would translate short and simple passages by himself, but rely on apps for longer, more complex passages. Most informants realized the machine translations were often problematic. Conceding that such translations were flawed, they relied on machine translations because they believed no free alternatives existed in the classroom time frames available. Paying for professional translations was not an option for the interviewees. Four of the interviewees regarded translation apps as useful expedients capable of producing "somewhat" correct results. Airi added, "If you have a friend who speaks English or the language you want to translate [into], I think you should talk to that friend..., but [if] you don't have any friend[s], then [apps are good]." [32:19].

$R Q$ 2: How did the undergraduates in this sample conceptualize the translation process?

The interviews suggest that none of the respondents thought deeply about translation issues prior to the exercises. They were accustomed to having teachers point out which of their sentence-level translations were "good" or not. They rarely worked with multiparagraph texts, except when giving speeches in English. Three respondents indicated they first outlined their speeches in their L1, then attempted to render them into English, often referring to online dictionaries or translation websites.

We could say that all of the informants had only rudimentary notions of translation. Unless they were taking a high-stakes test involving sentence-level translation problems, accuracy was not a concern. Daiki summarized this view by commenting: "If it is difficult to catch the full meaning of a text, the overall meaning suffices. Machine translation is good for that... it is especially helpful for long sentences." (12:45).

It seems fair to say that micro-level lexical-grammatical factors (rather than macrolevel socio-pragmatic factors) were the main drivers influencing how informants translated. Moorkens and O'Brien (2015) have also found that novice and experienced translators tend to work differently, with the latter group operating more quickly and post-editing more extensively.

RQ 3: What sort of errors did the students make when attempting translations?

Concerning the third research question, we should point out that all but one of the 86 translations of Exercise 1 had some errors. Rather than going through the entire exercise sentence-by-sentence, we will focus on two sentences that exemplify key problems.

The third sentence of the new year's card was: 今年も変わらぬお付き合いのほどよろしくお 願いいたします。 Five students produced Level 1 errors according to the typology of Fujita et al. (2017). They provided either no translation or else incomplete target language renditions of the text. Ten produced Level 2 semantic errors resulting in mistranslations, omissions, or unwarranted additions. One person rendered the text as, "I want to keep 
this close relationship," distorting the original nuance. Five texts had Level 3 errors exhibiting non-standard grammar, spelling, or punctuation. One contained a Level 4 error with the basic meaning of the source text intact, but resulting in an excessively literal translation. Four texts exhibited Level 5 social register errors. Since the source text was formal, any casual renditions would be inappropriate.

Forty-one of the respondents, however, satisfactorily translated the sentence. Surprisingly, 35 translated it in a way differing from any online translation engines. One hypothesis was that some students correctly translated this text while others copied their translations. Many students did work collaboratively in small groups and shared information. Another possibility was that some students successfully parsed lexical chunks from their cellphone apps, making minor morphological changes on the fly. The Weblio app, for example, provides useful snippets of parts of the sentence above. Our findings underscored the need for further research that includes video monitoring to ascertain how students translate in real time.

Now let us consider how students tackled the most difficult sentence in this translation exercise. The sixth sentence of the Japanese new year's card stated: お互い 健康に気をつけてがんばっていきましょう。 Nineteen of the students translated this literally as, "Let's do our best while taking care of each other's health." It is no coincidence that Google Translate renders the source text this way. The Japanese text contains a sort of "politeness myth" that seems odd if translated directly into English. Since non-family members are not responsible for each other's health, a free translation - or in Venuti's (1995) terminology, a more domesticated translation - "Please take care of your health." would be apt.

It is noteworthy that four respondents did not attempt to translate Example 2. Fujita et al. (2017) codes such non-attempts as Level 1 errors. Thirty students produced Level 2 semantic errors, characterized by mistranslations, omissions, or unwarranted additions. "Let's both take care of our health and work hard" mentions working hard $-\mathrm{a}$ factor not explicit in the original text. Thirty-two of the translations had Level 3 grammar, spelling, or punctuation errors. None had any Level 4 felicity errors, and only one exhibited a Level 5 social register error. The fact that only two of the respondents translated the Japanese text in a natural way underscores the difficulties that these kinds of translations can entail.
$R Q$ 4: To what extent, if any, did these activities change how the students regarded machine translations?

Responses to the final research question were varied. As Kaminska and Foulsham (2013) point out, interviews are fraught with social desirability bias, so it is difficult to ascertain whether any significant attitudinal or behavioral changes in the students resulted from these activities. The goal of the activities was to problematize the overuse of unedited machine translations. Five of the informants mentioned they understood this prior to the activities. Since informants felt that the resources mentioned in Appendix C were time-consuming to access, they echoed Reia's attitude: "Not using machine translation is ideal, but hmm ... [for] people who are not native speakers ... it is [sometimes] necessary" [28:10].

During the classroom discussions outlined in Appendix C, few informants underscored the importance of ascertaining the functional purpose-or what Reiß and Vermeer (2014) refer to as skopos-before starting a translation. These interviews underscored the need to emphasize that translation is not a monolithic process, but as an amalgam of complex choices. If translation seeks to gain insight into a target language, then literal translations are often appropriate. If the purpose is to facilitate ease of target language comprehension, freer translations are generally preferable. If a quick, rough sense of a text without any high-stakes is desired, machine translations generally suffice. Too often the informants considered translation as a largely semantic and grammatical exercise rather than as a social act. This echoes the observations summarized by Daems et al. (2017, par. 20) who state, "Inexperienced translators have been shown to treat the translation task as a mainly lexical task, whereas professional translators pay more attention to coherence and style." Most informants lamented their lack of access to fluent bilingual speakers who could help them with their translations: they believed only two choices existed - to either rely on guesswork or accept machine translations prima facie.

The interviews also made it clear that our pilot lessons needed three improvements: (1) The notion of functional purpose should be introduced early on, along with a distinction between what Japanese call choku-yaku (direct, foreignized translations) and i-yaku (applied, domesticated translations). Examples of both translation types should be provided soon after students complete the first exercise; (2) More information about ways to help novice student-translators improve their skills needs to be included; and (3) Depending on course purposes, target language proficiency levels, and participant interest, the overall material could be streamlined or expanded. 
(1) Framing translation within a functional approach

Many students seem to have simplistic grammar-based notions of "right" and "wrong" translations and little knowledge of different translation types. In the future, after Translation Exercise 1 is completed, we recommend handing out the Sample Translation Types in Appendix B. That worksheet shows how different desired textual outcomes should shape translation processes. Participants should also understand the conditions under which literal translations, free translations, or prima facie machine translations are also valid choices.

\section{(2) More translation resource information}

Translation resources should be presented after students complete the final Translation Exercise in Appendix B. This information includes (1) details about bilingual concordances, (2) summaries of some online peer translation services, and (3) information about volunteer translation groups in Tokyo

We also found that none of the interviewees were aware of any peer translation resources that use crowdsourcing. To reduce the reliance on machine translation, we recommend Hi-Native when working on short sentence-level texts and Lang-8 when working with longer passages. Since most interviewees made it clear that access to fluent English speakers was needed, we also recommend either the Tandem or the Language Exchange online volunteer networks.

Regarding real-time non-virtual resources, in Tokyo there are periodic meetings for volunteer translators. The Marco Polo Projects' Translation Club and the Tokyo Translator Study Group may be additional viable resources for some students.

\section{(3) Adjusting the material to suit specific classroom contexts}

A one-size-fits-all approach to translation is unlikely to work in all contexts. Linguistic proficiency, curricular goals, and student interest should be considered when designing activities. It was our intention to introduce a range of activities to our students. Because of space limitations, only the most successful three of the six activities that we employed are described here. The three activities that were not so successful had problematic features that should be examined in a futurepublication. We should concede that even the three "successful" C-R activities described herein did not work optimally for all of our students. For example, some Vietnamese students had difficulty understanding the nuances of the Japanese text and the weakest students relied most heavily on machine translations.

\section{Research Limitations}

Three limitations of the current study need to be mentioned:

First, the sampling is not representative of the Japanese tertiary student population. Five of the six interview informants were female and their reported TOEIC scores were above the Japanese norm. Those with substantially lower levels of English proficiency would likely respond differently to the activities outlined herein. Future studies should focus on students who are closer to an anticipated norm.

Second, problems of bilingual translations in multilingual contexts need to be addressed. Non-Japanese students with limited Japanese proficiency had trouble translating any Japanese language materials. This issue is especially acute for students with limited knowledge of Chinese characters: Chinese students can often guess the meaning of unknown words in kanji, but Korean or Vietnamese tend to be more perplexed by them.

A third limitation concerns methodology: this research relied on questionnaires, interviews, and non-systematic classroom observations. Future studies could also utilize journal entries, video recordings, and translation portfolios for finer nuanced data. A wider range of documents in broader portfolios may yield richer information.

\section{Conclusion}

In this paper, we have described the use of machine translation by 86 EFL learners at two educational venues in Japan. We probed into the way that students conceptualize the translation process and highlighted some salient errors in translation tasks. We explored the impact that C-R activities might have had on shaping student attitudes about machine translations. What we found was, despite knowing the results are often imperfect, many students over rely on machine translation and most have only basic notions regarding how to translate. It became clear that more students also need to view translation within a broader socio-cultural context.

\section{Acknowledgements}

Many thanks to Tom Gally and Hywel Evans for their comments and suggestions on this paper, as well as to Keiko Tonegawa and Chigusa Morita for their assistance with the translations. 
JALT2020

TEACHERS \& LEARNERS

\section{Bio Data}

Tim Newfields recently retired from Toyo University. He is a former JALT National Publicity Chair, National Recording Secretary, JALT Pan-SIG Proceedings Editor, Study Abroad SIG Journal Editor, and Testing \& Evaluation SIG Editor. His contact information and publications are online at www.tnewfields.info.

Ivan Botev holds an MEd in EFL and PhD in area studies. He currently serves as a tenured lecturer of English in the Department of International Communication and Culture at Toita Women's College, Tokyo, Japan. His areas of research are in children's literature, machine translation, and intercultural communication.

\section{References}

Balushi, K. A. (2018). The use of online semi-structured interviews in interpretive research International Journal of Science and Research, 7(4), 726-732. https://doi.org/10.21275/ ART20181393

Bardovi-Harlig, K., \& Griffin, R. (2005). L2 pragmatic awareness: Evidence from the ESL classroom. System, 33(3), 401-415. https://doi.org/10.1016/j.system.2005.06.004

Bolitho, R., \& Tomlinson, B. (1980). Discover English: A language awareness coursebook. Heinemann. Bruner, J. S. (1961). The act of discovery. Harvard Educational Review, 31, 21-32. https:// digitalauthorshipuri.files.wordpress.com/2015/01/the-act-of-discovery-bruner.pdf

Cheng, S. (2017). Translation competence development among learners: A problem-solving perspective An unpublished dissertation at the University of Manchester. https://www.research.manchester. ac.uk/portal/ files/64900825/FULL_TEXT.PDF

Daems, J., Vandepitte, S., Hartsuiker, R. J., \& Macken, L. (2017). Identifying the machine translation error types with the greatest impact on post-editing effort. Frontiers in Psychology, 8, Article 1282. https://doi.org/10.3389/fpsyg.2017.01282

Educational Testing Service. (2018). 2017 report of TOEIC test takers worldwide: TOEIC Listening and Reading Test. https://www.ets.org/s/toeic/pdf/2017-report-on-test-takers-worldwide.pdf

Ellis, R. (2002). Grammar teaching: Practice or consciousness raising? In J. C. Richards \& W. A. Renandya (Eds.), Methodology in language teaching (pp. 167-174). Cambridge University Press.

Fujita, A., Tanabe, K., Toyoshima, C., Yamamoto, M., Kageura, K., Hartley, A. (2017). Consistent classification of translation revisions: A case study of English-Japanese student translations. In N. Schneider \& N. Xue (Eds.), Proceedings of the 11th Linguistic Annotation Workshop, pp 57-66. https://doi.org/10.18653/v1/W17-08

Japan Post (n.d.). 年賀状文例集 [New Year's card sentence collection]. https://yu-bin.jp/letters/ phrases/
Jones, F. R. (2011). Poetry translating as expert action. Amsterdam: John Benjamins.

Kaminska, O., \& Foulsham, T. (2013). Understanding sources of social desirability bias in different modes: evidence from eye-tracking. ISER Working Paper Series 2013-04, https://www.iser.essex. ac.uk/research/publications/ working-papers/iser/2013-04.pdf

Kvale, S. (2008). Interviews: Learning the craft of qualitative research interviewing (3rd ed.). Sage. Lee, S. M. (2019). The impact of using machine translation on EFL students' writing. Computer Assisted Language Learning, 33(3), 157-175. https://doi.org/10.1080/09588221.2018.1553186

Li, L. (2017). Training undergraduate translators: A consciousness-raising approach. The Interpreter and Translator Trainer, 11(4), 245-258. https://doi.org/10.1080/1750399X.2017.1359757

Marco Polo Project. (n.d.). Translation Club. https://www.marcopoloproject.org/translation-club/

Mizuochi, Y., Kiryu, T., \& Kanzaki, H. (2012). 小学校外国語活動におけるタブレット型端末の音声認 識機能による翻訳活動に関する事例的研究 [A case study involving translation activities by voice recognition on tablet terminals for elementary school foreign language students]. Japan Journal of Educational Technology, 36, 45-48. https://doi.org/10.15077/jjet.KJ00008609773

Moorkens, J., \& O'Brien, S. (2015). Post-editing evaluations: Trade-offs between novice and professional participants. In I. El-Kahlout, et al (Eds.) Proceedings of the 18th Annual Conference of the European Association for Machine Translation, Antalya, Turkey. pp 75-81. https://www.aclweb. org/anthology/W15-4910.pdf

PACTE Group. (2005). Investigating translation competence: Conceptual and methodological issues. Meta, 50, (2) 2005, 609-619. https://doi.org/10.7202/011004ar

Reiß, K., \& Vermeer, H. J. (2014). Towards a general theory of translational action (C. Nord trans.). Routledge.

Reverso Technologies. (2013, 2020). ReversoContext. https://context.reverso.net/translation/

Rutherford, W. E. (1987). The meaning of grammatical consciousness-raising. World Englishes, 6(3), 209-216. https://doi.org/10.1111/j.1467-971X.1987.tb00201.x

Rutherford, W. E., \& Sharwood Smith, M. (1985). Consciousness-raising and Universal Grammar. Applied Linguistics, 6 (3), 274-282. https://doi.org/10.1093/applin/6.3.274

Sharwood-Smith, M. (1981). Consciousness-raising and the second language learner. Applied Linguistics, 2(2), 159-167. https://doi.org/10.1093/applin/1l.2.159

Tatsumi, A. (2015). 大学英語教育における翻訳指導に関する研究:一般英語授業での翻訳指導実践を 事例として [A study of the teaching of translation in university English education: A practical translation lesson in a general English class]. 翻訳研究への招待 [Invitation to Translation Studies], 13, 67-82. https://honyakukenkyu.sakura.ne.jp/shotai_vol13/No_13-004-Tatsumi.pdf Tokyo Translator Study Group. (n.d.) www.meetup.com/Tokyo-Translator-Study-Group/ 


\section{JALT2020}

COMMUNITIES OF
TEACHERS \& IEARNERS
Tomlinson, B. (1994). Pragmatic awareness activities. Language Awareness, 3(3-4), 119-129. https:// doi.org/10.1080/09658416.1994.9959850

Tomlinson, B. (2003). Developing materials for language teaching. Continuum.

Venuti, L. (1995). The translator's invisibility: A history of translation. Routledge.

\section{Appendix A}

Translation Exercise 1

私たちは、大学生がごのように日本語から英語に翻訳するかについての研究を行っています。以下 の文章を見て、可能な限り英語に翻訳してください。このアクテイビティを行うには10分かかります。 スマートフオンを使用してオンライン翻訳サービスに接続することも、オンラインサービスなしで自 分で行うこともできます。このアクテイビテイは、皆さんが履修するコースの成績に影響を与えるこ とは一切ありません。ペナルティなしで参加を拒否する権利があります。この質問紙はアクティビテ イの最後に回収し、すべての結果は、個人情報が特定される事はにありません。この質問紙に名前 は書かないでください。ただし、性別、母国語、使用したデジタル翻訳サービス名を記入してくださ い。さらに質問がある場合は、以下の研究者に連絡してください。

Timothy Newfields (email address*) Ivan Botev (email address*)

明けましておめでとうございます

昨年はいろいろと心づかいをいただきありがとうございます。 今年も変わらぬお付き合いのほどよろしくお願いいたします。

仕事もプライベートも充実した日々を送っています。

今年は再会を果たしたいですね。

お互い健康に気をつけてがんばっていきましょう。

使用したオンライン翻訳サイト / Online Translation Cites Used:

性別 / Gender: 母語 /

Native Language:

* To reduce spam, the email addresses do not appear in this published version.

\section{Appendix B}

Introducing Translation Types to Students

In a sense, there are three basic types of translations. One type, known as a 「直訳 $\rfloor$ in Japanese or a "direct translation" in English, tries to maintain the source text as faithfully (忠実) as possible. Another type, known as a 意訳 or a “free translation” or “applied translation" in English, changes the source text to seem as natural as possible in the target language. A third type, known as a「機械訳」in Japanese or a "machine translation" in English, renders a source text quickly into a target language without human editing. To illustrate the differences, consider the following examples:

\section{原文 Source Text:}

1 明けましておめでとうございます 2 昨年はいろいろと心づかいをいただきありがとうございま す。 3 今年も変わらぬお付き合いのほどよろしくお願いいたします。 4 仕事もプライベートも 充実した日々を送っています 5 今年は再会を果たしたいですね。6 お互い健康に気をつけて がんばっていきましょう。

\section{一つの直訳One Possible Direct Translation:}

1 New Year Congratulations! 2 Last year thank you for various $<$ heartful $>$ caring. 3 This year too, without change please $<$ humbly $>$ socialize [with me]. 4 Work and private life are $<$ spent in $>$ fulfilling $<$ days $>$. 5 This year [let's] carry out a reunion, $<$ right? $>6$ Let's try to take care of each other's health.

\section{人間による編集後の一つの自由訳One Free Translation with Human Post-Editing:}

1 Happy New Year. 2 Thanks for your kindness last year. 3 I look forward to meeting your further this year. 4 These days I'm pleased to say work is fulfilling. 5 Let's get together sometime later this year. 6 Please take care of your health.

一つの可能な機械翻訳One Possible Machine Translation: (Source: Microsoft Bing Translation) 1 Happy New Year. 2 Thank you for all the considerations we had last year. 3 Thank you so much for your continued relationship this year. 4 I have a fulfilling life in my work and private life. 5 I want to see you again this year. 6 Let's take care of each other's health and do our best. 


\section{Discussion Questions}

Instructions: Discuss these questions in small groups, then the class as a whole.

1. How do the direct and applied translations differ?

2. Did you notice anything cultural inappropriate in the direct translation?

3. When are direct translations sometimes be useful?

4. When should direct translations be avoided?

5. When are free translations sometimes useful?

6. When should free translations be avoided?

7. When do you feel machine translations are useful?

8. When should machine translations be avoided?

\section{Agree or Disagree}

Instructions: Agree or disagree these statements in pairs, then discuss them with the whole class.

1. Generally, direct translations are "bad."

2. Usually, applied translations are "good."

3. To learn a foreign language, it is best to avoid translation.

4. Most computer translations are handy (便利, convenient).

5. Most computer translations are faithful (very close to the source text).

\section{Appendix C}

Translator Training Resources

(1) Online bilingual concordances

A concordance is list of words appearing in a text passage. It shows you how those words are used in actual situations. Here are three useful online concordances available as cellphone apps and websites.
- Linguee
(linguee.com)
25 languages
- Reverso-Context
(context.reverso.net/translation/)
- Weblio

(2) Online peer translation services

- HiNative (hinative.com) a useful resource if you want sentence-level corrections

- Lang-8 (lang-8.com) 17 languages often useful when working with longer passages

- Language Exchange (ja.language.exchange) offers peer-to-peer language exchanges

- Tandem (tandemexchange.com) another way to link up with foreign language learners

90 languages

13 languages

20 languages

(3) translation groups in Tokyo

- Marco Polo Project (meetup.com/Japanese-and-English-All-You-Can-Translate) holds weekly meetings in Yotsuya

- Tokyo Translator Study Group (meetup.com/Tokyo-Translator-Study-Group) periodically meets near Shinjuku

- Japan Association of Translators /日本翻訳者協会 (jat.org) Interested in becoming a professional translator? This is a good resource

\section{Discussion Questions}

Instructions: Discuss these questions in small groups, then the class as a whole.

1. What are the merits and demerits of using bilingual concordances?

2. Which of the online peer translation services seem most interesting to you?

3. What precautions should you take when using online forums?

4. How interested are you in attending a peer translation group?

\section{Appendix D}

Semi-Structured Interview Questions

NOTE: Since the English proficiency level of the respondents varied and both interviewers were fluent in Japanese, if the informants had difficulty responding to a question in English, Japanese was used. Also, prior to the interview an informed consent statement was given verbally to all informants and none of them opted out. 
Part I. Introductory Questions

1. To protect your privacy no real names will be used in this research. Can you choose a nickname that we can use? プライバシーを保護するため、本調査では本名を使用しませ ん。本調査で使用するニックネームを教えてください。

2. What languages do you speak? 普段使用する言語は何ですか。

3. How old are you now? 現時点での年齢を教えてください。

4. What was your most recent TOEIC score? 最後に受けたTOEICのスコアを教えてくださ W。

5. Can you briefly summarize your English language learning history?これまでの英語学 習歴を簡単に教えてください。

6. What foreign countries have you visited so far? (And for how long?) これまで訪れたこと のある外国はどこですか。またどのくらいの期間滞在していましたか。

7. Do you have a cellphone? 携帯電話を持っていますか。

8. On that cellphone, do you have any electronic dictionaries? (If so, which ones?) あな たの携帯電話には電子辞書が搭載されていますか。(その場合、何という辞書ですか)

9. On your cellphone, do you have any translation apps? (If so, which ones?) あなたの携 帯電話には翻訳アプリが搭載されていますか。(その場合、何というアプリですか)

If respondents answered “yes” then ask - 答えが「はい」場合、次の質問に答えてくださ い。

(a) When did you last use that(those) cellphone translation app(apps)? 携帯電話の翻訳 アプリを最後に使用したのはいつですか。

(b) How often do you use that(those) app(apps)? どのくらいの頻度で携帯電話の翻訳アプ リを使用しますか。

10. Do you have a computer? パソコンは持っていますか。

11. Which online translation sites do you use, and how often? 次のうちどの翻訳サイトを使 用しますか。またどのくらいの頻度で使用しますか。

12. How would you rate the quality of each of the translation services you have used? れまで使用した翻訳サービスの質に関してどのように評価しますか。

13. What materials have you translated from Japanese into English? ごのような文(章)を日 本語から英語に翻訳したことがありますか。

14. What materials have you translated from English into Japanese? ごのような文(章)を英 語から日本語に翻訳したことがありますか。
15. In your view, what is a “good translation”? あなたの考えでは、よい翻訳とはどのようなも のですか。

16. When have to write a school paper in English, do you prefer to write part of that paper in your native language first, and then translate it into English - or do you prefer to work directly in English? 英語で文を書かなくてはならない場合、母国語で書い た後にその文章を英語に翻訳すしますか。あるいは最初から英語を使いますか?

17. When translating a document what do you think is most important? 文書を翻訳する ときにいちばん大切なことは何だと思いますか。

18. How would you describe your preferred translation style? あなたの好みの翻訳スタイル はごのようなものですか。

19. Generally speaking, do you enjoy translating? 概して翻訳することは好きですか。

20. In your view, how important is it to be able to translate between two or more foreign languages? あなたの考えでは、2か国語以上の言語間の翻訳ができることはどのくらい重要な ことですか。

Part II. Questions about Classroom Materials

Now let's take a look at the classroom handouts that we distributed in December and January.

[Show the Translation Exercise in Appendix A]

1. About how long did it take you to translate that post card? そのはがきを翻訳するのにど のくらい時間がかかりましたか。

2. Did you use any apps to check your translation? (If so, which ones?) そのとき、何かアプ リを使用しましたか。(使用した場合、どのアプリを使用しましたか)

3. Were there any words or phrases you felt unsure how to translate? (If so, which ones?) どのように翻訳したらよいかよく分からない単語や語句はありましたか。(ある場合、ど の単語や語句ですか)

[Show the Translation Exercise in Appendix B]

4. In your view, how accurate were the computer translations of the Japanese? あなたの 考えでは、このコンピューターによる日本語のテキストの翻訳はどのくらい正確だと思います か。

5. What problems did you notice about the computer translations? コンピューター翻訳に ついての 問題点に気が付きましたか。 


\section{JALT2020}

COMMUNITIES OF

6. Did this activity have any clear goal or purpose? あなたにとって、この活動ははっきりした 目 標や目的がありましたか。

[Show the Translation Exercise in Appendix C]

7. Was it easy or difficult for you to judge which of the computer translations seemed “best”?どのコンピューター翻訳がもつともよいと思えるかを判断するのは、あなたにとって簡 単でしたか、難しかったですか。

8. What problems did you notice about these computer translations?これらのコンピュー ター翻訳についての問題点に気が付きましたか。

9. Did you learn anything by doing this activity? (If so, what?) この活動を行うことで、何か 得られたものはありますか。(ある場合、それは何ですか)

Part III. Agree or Disagree

Now I would like you to either agree or disagree with each of the following statements.

Please feel free to comment as much as possible on each statement.

10. Today most English-Japanese computer translations are basically accurate.「今日、ほと んどの英日コンピューター翻訳は基本的に正確だ。

11. It is better not to use machine translation services.「機械翻訳サービスを使用しないほう がよい。」

12. The classroom activities didn't really change my ideas about machine translation.「教 室での活動は機械翻訳に関する私の考えをあまり買えるものではなかった。」

13. When I read a document, I can usually tell whether it is the result of a machine translation or a human translation.「文書を読んだ際、それが機械翻訳によるものか人間 の翻訳によるものかをだいたい区別をすることができる。

14. I understand the difference between a direct translation and an adapted (or free) translation.「直訳」と「意訳」や「自由訳」の違いを理解しましす。

15. I understand the difference between a mistranslation and a transliteration. 「誤訳」と「 音訳」の違いを理解しましす。 